\title{
GALERI SENI MUSIK TRADISIONAL TIONGHOA
}

\author{
Febrianto Candra $^{1)}$, Lina Purnama ${ }^{2)}$ \\ 1) Program Studi S1 Arsitektur, Fakultas Teknik, Universitas Tarumanagara, cfebrianto89@yahoo.com \\ 2) Program Studi S1 Arsitektur, Fakultas Teknik, Universitas Tarumanagara, Ipurnama.112@gmail.com
}

\begin{abstract}
Abstrak
Jakarta merupakan ibukota dan juga salah satu kota metropolis yang ada di Indonesia, yang memiliki berbagai macam budaya seni. Budaya seni di Jakarta seperti budaya seni Betawi terbentuk dikarenakan adanya pengaruh kebudayaan Tionghoa yang masuk ke Indonesia. Salah satu budaya yang memberikan pengaruh pada budaya Betawi adalah seni musik tradisional Tionghoa yang melahirkan seni musik Betawi, Gambang Kromong. Dari sejarah ini dapat dikatakan bahwa keberagaman dan toleransi menjadi salah satu poin penting yang mendukung kekayaan kebudayaan Indonesia. Dengan adanya pengetahuan mengenai sejarah budaya Tionghoa terhadap budaya Betawi di Jakarta bertujuan untuk memberikan sebuah ruang pendekatan masyarakat agar dapat menciptakan toleransi antar masyarakat di Jakarta dan juga memberikan pengetahuan mengenai budaya seni musik tradisional Tionghoa kepada masyarakat lokal hingga mancanegara. Perancangan dari Wisata Galeri Seni Musik Tradisional Tionghoa ini dilakukan dengan melakukan pencarian data dengan melakukan survei di kawasan Pintu Besar Selatan, Kota Tua serta mengkaji literatur. Berdasarkan hasil survei dan wawancara, lokasi pintu besar selatan sering digelar pagelaran seni musik tradisional yang berlokasi di jalan yang mengakibatkan penutupan jalan. Sehingga program wisata yang direncanakan tidak hanya menyajikan wisata galeri seni musik tradisional Tionghoa. Tetapi juga turut ikut serta dalam menyajikan ruang publik yang dapat digunakan oleh masyarakat sekitar dalam melakukan pagelaran seni musik tradisional dengan menggunakan alat musik tradisional baik Tionghoa maupun alat musik lainnya. Dengan adanya bangunan ini, diharapkan tidak hanya memberikan edukasi tetapi juga dapat menciptakan rasa toleransi antar masyarakat Tionghoa dengan masyarakat lokal.
\end{abstract}

Kata kunci: Galeri, Metropolis, Musik, Tradisional, Tionghoa

\begin{abstract}
Jakarta is the capital city and also one of metropolis city in Indonesia, which has various kind of art and culture. The art and culture in Jakarta, such as Betawi art culture was formed because of influence from Chinese culture that enter Indonesia. one of the cultures that gave influence to Betawi culture was Chinese traditional music which gave birth to Betawi music, Gambang Kromong. From this history it can be said that diversity and tolerance are one of the important points that support the richness of Indonesian culture. The knowledge of the history of Chinese culture towards Betawi culture in Jakarta aims to provide a space for a community approach to create tolerance between people in Jakarta and also provide knowledge about the traditional culture of Chinese music to local and foreign communities. The design of this tourism was carried out by conducting data searches in the Pintu Besar Selatan, Kota Tua and reviewing the literature. Based on the results of surveys and interviews, the location of the Pintu Besar Selatan is often held by traditional music performances located on the street resulting in street closures near Jakarta chinatown. So that the planned tourism program not only serves traditional Chinese music art galleries, but also participated in presenting public spaces. The Project could be used by the surrounding community in performing traditional music art performances using traditional Chinese instruments and other musical instruments. With the existence of this building, it is expected not only to provide education but also can create a sense of tolerance among the Chinese community with the local community.
\end{abstract}

Keywords: Gallery, Metropolis, Music, Traditional, Tionghoa 


\section{PENDAHULUAN}

\section{Latar Belakang}

Kota Jakarta merupakan ibukota dan juga salah satu kota metropolis di Indonesia yang memiliki berbagai macam budaya. Budaya seni musik Tionghoa memiliki sejarah yang tidak kalah penting di Indonesia. Dimana budaya Tionghoa yang dibawa dari penduduk Cina ke Jakarta seperti Seni Musik Tradisional Tionghoa menciptakan sebuah pembauran dalam budaya-budaya Betawi salah satunya dalam bidang Seni Musik yaitu, Gambang Kromong. Dari sejarah ini, dapat dikatakan bahwa keberagaman dan toleransi menjadi salah satu poin penting dalam hal yang mendukung kekayaan kebudayaan Indonesia.

Kebudayaan Tionghoa di Jakarta cenderung tertutup dan hanya ditampilkan di beberapa lokasi saja. Dikarenakan kebudayaan masyarakat Tionghoa sempat dilarang ketika masa orde baru karena dianggap sebagai sebuah ancaman dalam menularkan paham komunisme di Indonesia. Peraturan inilah yang memberikan sebuah pandangan negatif masyarakat di Jakarta terhadap kebudayaan Tionghoa yang ada di Jakarta.

Oleh karena itu, untuk mewujudkan pembauran serta rasa toleransi masyarakat lokal terhadap Masyarakat Tionghoa. Program desain wisata yang diangkat adalah Galeri Seni Musik Tradisional Tionghoa. Yang bertujuan untuk memberikan wisata edukasi pada wisatawan lokal hingga mancanegara mengenai sejarah budaya seni musik dan cara memainkan alat musik tradisional Tionghoa di Jakarta.

\section{Rumusan Masalah}

Bagaimana wisata seni musik tradisional Tionghoa bisa menjadi sebuah atraksi kota metropolis? Bagaimana menumbuhkan minat masyarakat Tionghoa mengenai budaya seni musik tradisional? Bagaimana seni musik tradisional Tionghoa dapat menghubungkan masyarakat?

\section{Pembatasan Masalah}

Untuk membantu penelitian yang lebih terarah dan menghindari pembahasan menjadi terlalu luas, maka penulis perlu membuat batasan-batasan masalah yang diteliti yaitu Seni musik tradisional yang difokuskan dalam galeri ini adalah mengenai seni musik tradisional Tionghoa dan lokasi kota metropolis yang diteliti adalah kota Jakarta

\section{Maksud dan Tujuan}

Dalam menampilkan keunikan Indonesia dalam keberagaman, dimana keberagaman menjadi salah satu daya tarik Indonesia dalam hal pariwisata. Oleh karena itu, untuk menampilkan keberagaman Indonesia pada wisatawan lokal dan mancanegara tidak akan tercipta apabila tidak adanya toleransi dari masyarakat lokal sendiri. Dengan membuat program desain ini bertujuan untuk memberikan sebuah wisata sejarah dan edukasi mengenai salah satu budaya Indonesia mengenai seni musik tradisional Tionghoa dan juga untuk menciptakan rasa toleransi bagi masyarakat lokal melalui wisata Galeri Seni Musik Tradisional Tionghoa.

\section{Metodologi Pembahasan}

Memperoleh data-data dengan melakukan survey di lokasi tapak dan lokasi yang bersangkutan dengan lokasi tapak dan proyek yang akan dirancang. Memperoleh data-data dari internet berupa artikel, berita, e-book, dan jurnal ilmiah

\section{Sasaran Proyek}

Sasaran dari proyek Galeri Seni Musik Tradisional Tionghoa adalah untuk memberikan edukasi mengenai seni musik tradisional Tionghoa yang ditujukan terutama kepada masyarakat lokal Tionghoa dan masyarakat lokal di Jakarta untuk saling mempelajari budaya 
Tionghoa dan budaya lain seperti Betawi. Agar masyarakat dapat saling merangkul untuk menciptakan sebuah toleransi budaya.

\section{METODE}

Pengumpulan data dilakukan dengan mencari data literatur dari internet, melakukan survei dan melakukan wawancara kepada masyarakat di lokasi Pintu Besar Selatan, Kota Tua. Kumpulan data ini yang digunakan sebagai penelitian terhadap proyek penelitian perancangan yang berjudul Galeri Seni Musik Tradisional Tionghoa.

\section{DISKUSI DAN HASIL}

\section{Architourism}

Pariwisata arsitektur dan arsitektur pariwisata merupakan sebuah pengertian yang berbeda. Pariwisata arsitektur lebih tertuju pada sebuah karya arsitektur sebagai tempat wisata. Sedangkan arsitektur pariwisata lebih kepada program wisata terhadap karya arsitektur. Arsitektur pariwisata disebut juga sebagai atraksi wisata. Atraksi wisata ini dibagi menjadi Alam, bangunan yang dibangun tetapi bukan untuk menarik wisatawan, bangunan yang dibangun untuk menarik wisatawan, dan acara special tertentu.

\section{Architourism of the Metropolis}

Metropolis adalah kota besar atau konurbasi yang merupakan pusat ekonomi, politik, dan budaya yang signifikan untuk suatu negara atau wilayah, dan pusat penting untuk koneksi, perdagangan, dan komunikasi regional atau internasional. Istilahnya adalah Yunani Kuno dan berarti "ibukota" dari sebuah kota yang mengirimkan pemukim. Yang kemudian digeneralisasikan ke kota yang dianggap sebagai pusat kegiatan tertentu, atau kota besar yang penting disuatu negara.

Arsitektur dan ruang kota akan selalu berubah-ubah seiring waktu. Perubahan dari ruang kota juga akan dialami dalam setiap kota, hanya saja pengambilan langkah setiap kota berbeda-beda ada yang sengaja melakukan pembekuan terhadap beberapa karya arsitektur di zaman tertentu untuk memberikan kesan nilai sejarah pada kawasan tersebut sehingga dapat menarik wisatawan yang datang. Dalam kasus tertentu, beberapa kota memilih untuk merekonstruksi nilai sejarah yang ada pada lokasi yang telah mulai pudar atau sudah hilang. Turis yang darang tidak akan menyadari kapan karya arsitektur ini terbangun pada lokasi tersebut.

\section{Galeri Seni}

Galeri seni adalah sebuah bangunan atau ruang kosong yang bertujuan untuk melakukan pameran seni, yang pada umumnya merupakan karya seni rupa. Museum seni dapat berupa publik dan privat. Benda seni yang sering dipajang adalah lukisan, patung, seni dekoratif, furnitur, tektil, kostum, gambar, pastel, kolase, seni grafis, foto, benda bersejarah dan seni instalasi. Galeri seni tidak hanya dipergunakan sebagai tempat pameran karya seni, karena galeri seni juga bisa dipergunakan untuk menyelenggarakan kegiatan seni lainnya, seperti seni pertunjukan dan konser musik.

\section{Tema Bangunan}

Konsep dan tema bangunan galeri musik ini diambil dari tampilan alat musik tradisional Tionghoa, Yanqin. Alat musik ini memiliki 2 jenis nada yaitu nada tinggi dan rendah yang kemudian diterapkan menjadi pembentukan massa bangunan galeri. Bagian pertama adalah fungsi galeri dan bagian kedua digunakan sebagai fungsi pendukung untuk galeri. 


\section{Proses Gubahan Massa}

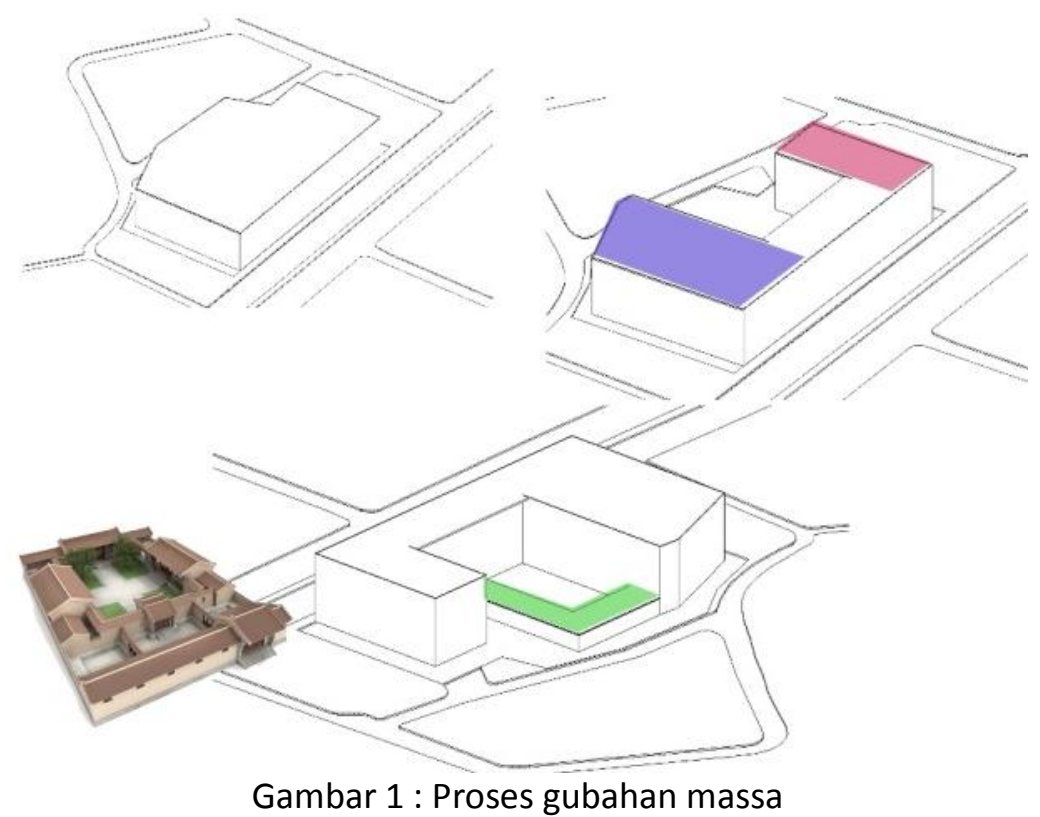

Budaya seni musik tradisional Tionghoa kerap dilupakan dan tidak terlalu terekspos di Jakarta. Dikarenakan kebudayaan Seni musik tradisional Tionghoa kurang diketahui dan tidak menarik minat bagi masyarakat Tionghoa. Adapun faktor lain yang turut mempengaruhi pandangan masyarakat terhadap kebudayaan Tionghoa yaitu ketika pada saat zaman orde baru dimana kebudayaan Tionghoa dilarang untuk diekspresikan menjadikan masyarakat memiliki trauma dan juga memilih untuk melupakan budayanya sendiri.

Oleh karena itu, proyek desain yang diusulkan memiliki tujuan yaitu memberikan edukasi mengenai kebudayaan seni musik Tionghoa bagi pengunjung maupun masyarakat dan juga memberikan sebuah wisata dan sebagai wadah aktivitas masyarakat mengenai budaya seni musik tradisional Tionghoa dan yang lainnya.Proyek desain ini memiliki konsep perancangan yaitu Minoritas untuk mayoritas. Dimana konsep ini mengangkat kebudayaan minoritas untuk diperkenalkan dengan wisatawan lokal dan mancanegara. Sehingga dengan adanya pengenalan wisata edukasi ini memberikan kesempatan bagi masyarakat Tionghoa untuk berbaur dan menunjukkan kebudayaan seni musik tradisional Tionghoa.

\section{Analisis Program}

Program wisata yang direncanakan berdasarkan dengan tujuan, kebutuhan, dan aktivitas masyarakat. Program ini disajikan dalam bentukgaleri yang menyediakan tempat komunitas bagi masyarakat dalam beraktivitas, bersantai, dan melakukan acara musikal. Edukasi pada galeri menjadi salah satu langkah dalam ruang pendekatan pada budaya dan masyarakat. 


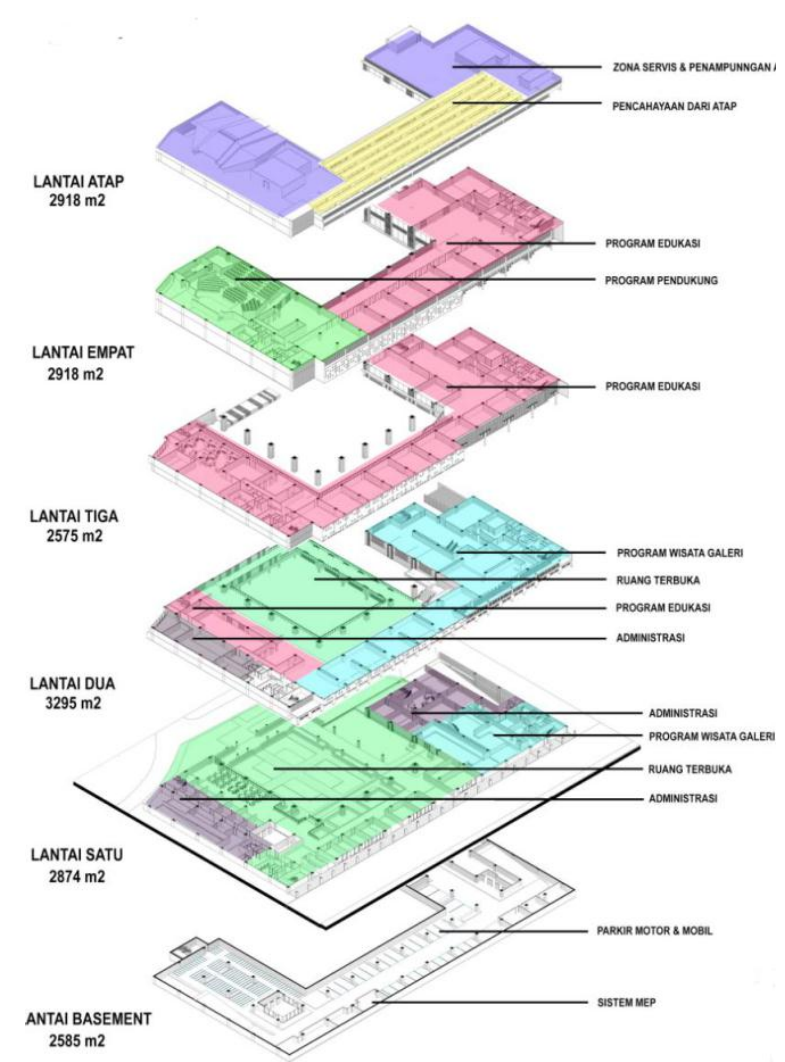

Gambar 2 : Analisa Program per Lantai

\section{KESIMPULAN DAN SARAN}

Dalam melaksanakan perancangan wisata arsitektur sebagai wisata sejarah dan edukasi di ibukota Jakarta, dilakukan perancangan dengan menulusuri sejarah lokasi perancangan dan aktivitas masyarakat yang terjadi pada masa lalu hingga masa sekarang.

Seperti dalam lokasi Kota Tua, yang terletak di Pintu Besar Selatan, berdekatan dengan pecinan Jakarta merupakan zona revitalisasi Kota Tua ke 3. Di mana pada zona ini terdapat beberapa peraturan desain yang harus diperhatikan dalam hal memberikan keserasian antara bangunan lama dengan bangunan baru. Lokasi tapak terdapat aktivitas budaya berupa seni musik tradisional yang dilaksanakan dalam 3 bulan sekali yaitu berupa sebuah pentas musik bagi masyarakat sekitar. Setelah dilakukan beberapa pertimbangan antara aktivitas masyarakat dan sejarah lokasi, aktivitas yang terjadi terlihat dampak bangunan sekarang tidak lagi memperhatikan peraturan dan sewaktu-waktu jalan ditutup untuk acara pagelaran seni musik, sehingga membuat kemacetan disekitar akses jalan lain di sekitarnya.

Galeri Seni Musik Tradisional Tionghoa diusulkan sebagai wisata arsitektur di ibukota Jakarta dalam membantu merevitalisasi Kota Tua dan mewadahi aktivitas masyarakat dalam melestarikan seni musik tradisional khusunya Seni Musik Tradisional Tionghoa. Dengan aktivitas seni musik yang diwadahi dapat dipromosikan kepada generasi muda dan turis asing agar dapat menjembatani identitas seni musik tradisional Tionghoa pada masyarakat kota Jakarta dan mancanegara. 


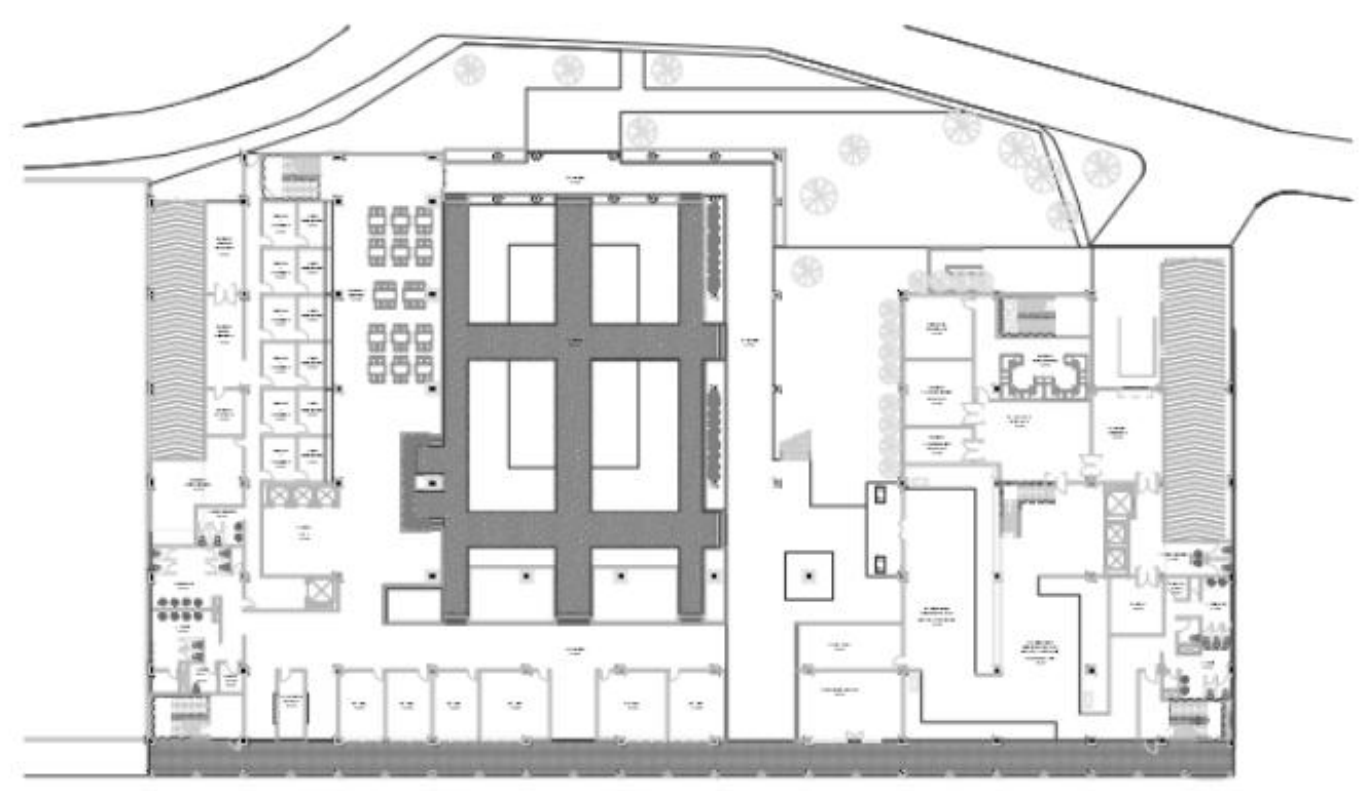

Gambar 3. Denah Lantai

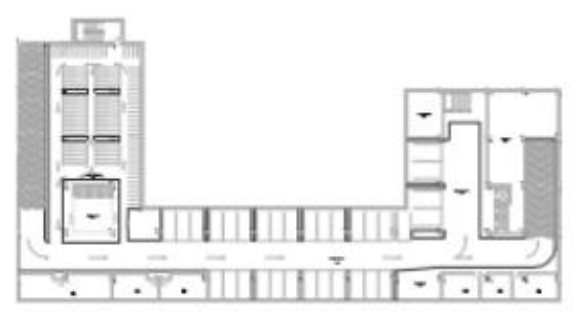

Gambar 4. Denah Basement

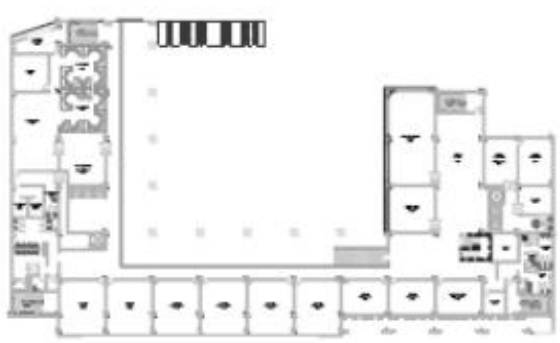

Gambar 6. Denah Lantai Tiga

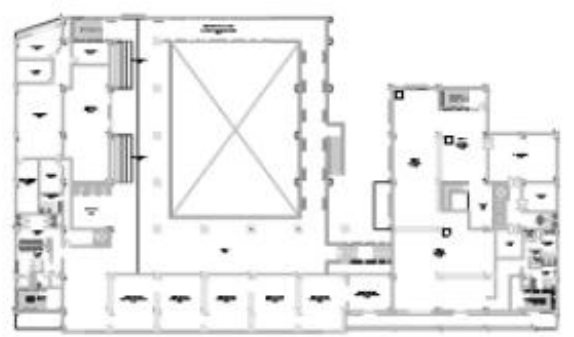

Gambar 5. Denah Lantai Dua

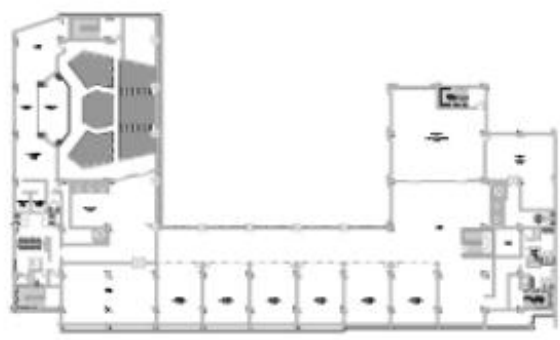

Gambar 7. Denah Lantai Empat

Berdasarkan hasil dari data dibuat ruang komunal di bagian tengah yang diapit oleh dua fungsi yang berbeda. Satu bagian bangunan adalah galeri seni musik dan edukasi seni musik, lainnya adalah kantor, komersial, dan teater musik. 


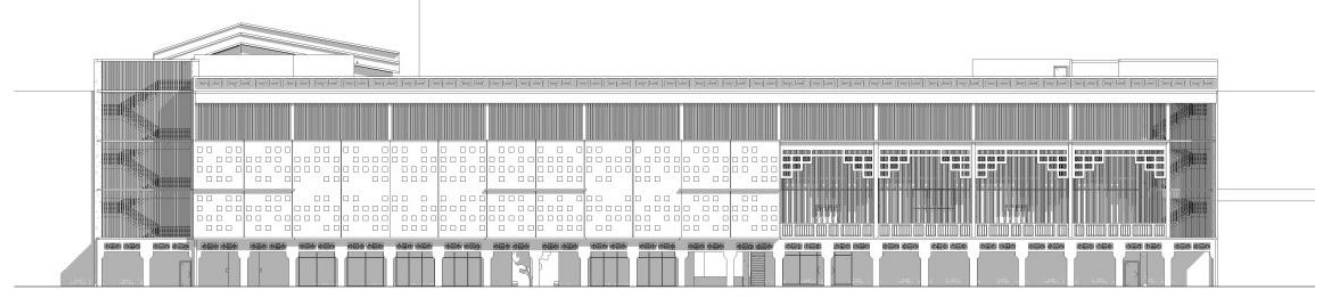

Gambar 8. Tampak Depan Bangunan

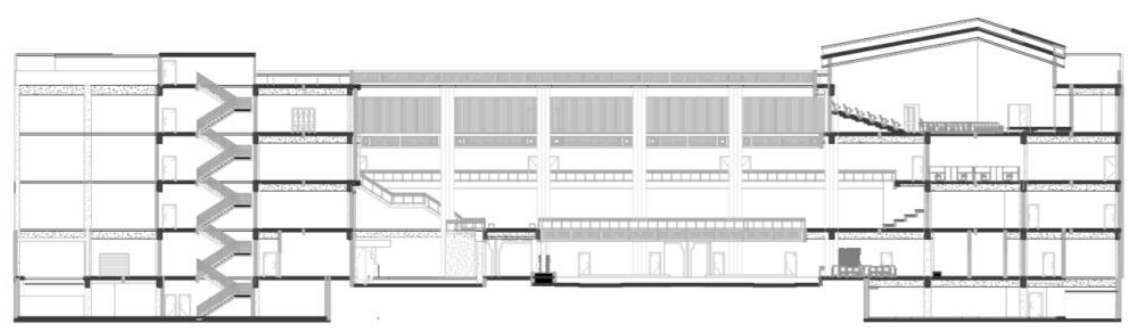

Gambar 9. Potongan Bangunan 1

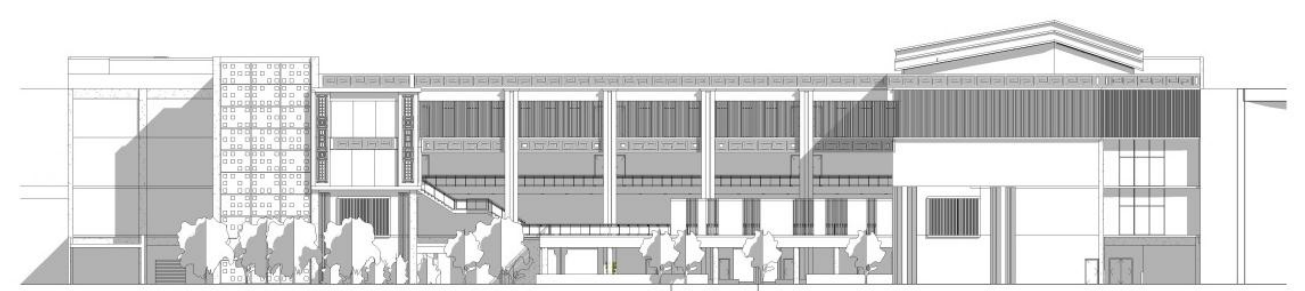

Gambar 10. Tampak Belakang Bangunan

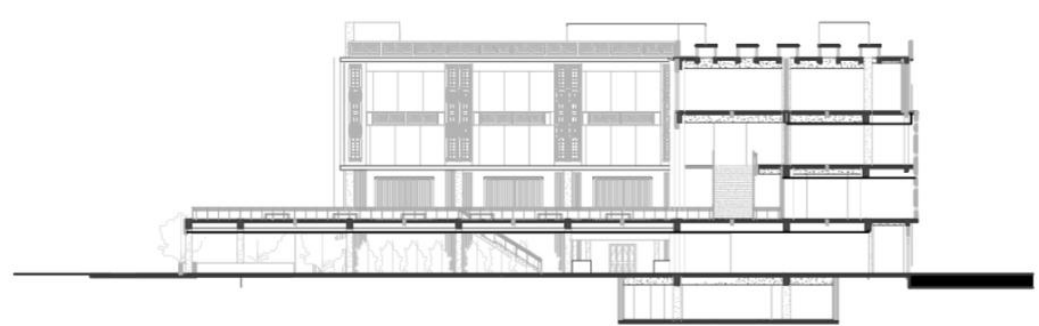

Gambar 11. Potongan Bangunan 2

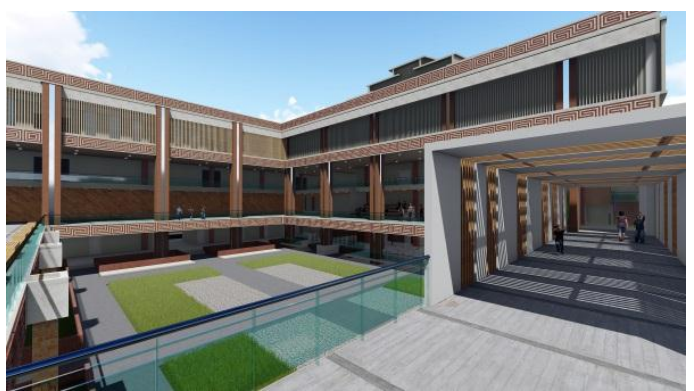

Gambar 12. Perspektif Ruang Komunal

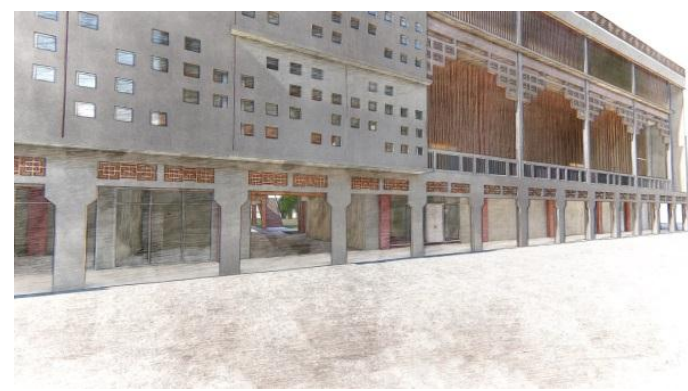

Gambar 13. Perspektif Depan Bangunan 


\section{UCAPAN TERIMA KASIH}

Penulis mengucapkan terima kasih kepada dosen fasilitator, orang tua, teman - teman, dan masyarakat lokal Pintu Besar Selatan dalam memberi dukungan dan data dalam merancang projek Galeri Seni Musik Tradisional Tionghoa.

\section{REFERENSI}

Archdaily. (2009). Muziekgebouw / 3XN, diunduh 16 Juni 2018, https://www.archdaily.com/38816/muziekgebouw-3xn

Archdaily. (2011). Freight \& Salvage Coffehouse / Marcy Wong Donn Logan Architects, diunduh 16 Juni 2018, https://www.archdaily.com/111580/freight-salvage-coffeehouse-marcywong-donn-logan-architects

Archdaily. (2016). Neushoorn / DP6 architectuurstudio + 3 TO architects, diunduh 16 Juni 2018, https://www.archdaily.com/784966/neushoorn-dp6-architectuurstudio-plus-3to-architects

Archdaily. (2018). Discovering Taiwan/Studio Ting, diunduh 16 Juni 2018, https://www.archdaily.com/891246/discovering-taiwan-studio-ting

Arjawinangun Bagja, Komaruddin. (2018). Kawasan Wisata Kali Besar Dibuka untuk Umum, Sandi: Tambah Aparat Satpol PP, diunduh 16 Juni 2018, https://metro.sindonews.com/read/1319689/171/kawasan-wisata-kali-besar-dibukauntukumum-sandi-tambah-aparat-satpol-pp-1530932286

Armandani, Karina. (2014). RI Panen Emas di Ajang Budaya Internasional, diunduh 15 Juni 2018, https://www.cnnindonesia.com/hiburan/20140903165934-241-2407/ri-panen-emasdi-ajang-budaya-internasional?

Chun Jiang, Fu. (2009). Chinese History. PT. Gramedia. Jakarta

Cole, Emily. (2002). The Grammar of Architecture. The Ivy Press. East Sussex

H.M, Zaenuddin. (2018). Asal-usul Djakarta Tempo Doeloe. PT. Buku Pintar Indonesia. Jakarta

Kawuwung, Daniel. (2012). Ciri-ciri kota metropolitan, diunduh 15 Juni 2018, http://danielkawuwung.blogspot.com/2012/08/ciri-ciri-kota-metropolitan.html,

Pei Ki, Goh. (2002). Origins of Chinese Festivals. PT. Gramedia. Jakarta

S, Marcus. (2002). Hari-hari Raya Tionghoa. Marwin. Jakarta Specht, Jan. (2014). Architectural Tourism. Springer Gabler. Wiley-Blackwell. (2012). Neufert Architect Data. Oxford Xiao Xiang Li. (2010). Origins of Chinese Classical Literature. PT. Gramedia. Jakarta 